\title{
Investigation of Effect of Body Mass Index of Patient Radiation Dose During Interventional Cardiac processes
}

\author{
Asmaa Salah $^{1}$, H.A.Abdel Ghany ${ }^{2}$,Ahmed A. Taha ${ }^{1}$ and H.M.Diab ${ }^{1}$ \\ ${ }^{1}$ Radiation Protection department, Nuclear \& Radiological Regulatory Authority (ENRRA), \\ Nasr City, Cairo , Egypt \\ ${ }^{2}$ Department of Physics, Faculity of Women for Arts, Science and Education, Ain-Shams \\ University, Cairo, Egypt
}

\begin{abstract}
Interventional cardiology is commonly performed under fluoroscopic guidance. Radiation exposure of patients and providers has not been comprehensively studied, particularly the effect of Body Mass Index (BMI). In the present study, an evaluation of the radiation dose received by patient during diagnostic and interventional cardiology was investigated and correlated with patient's (BMI). Real-time monitoring of radiation doses was performed for 60 patients aged from new born to 32 years old and was classified in five groups depending on their BMI as follows: (BMI < 10), (BMI: 10-15), (BMI: 15-20), (BMI: 20-25) and (BMI: 25-30).

The results showed that, Patient doses were ranged from $\left(0.9-4.3 \mathrm{~Gy} . \mathrm{cm}^{2}\right)$ with an average 2.9 Gy. $\mathrm{cm}^{2}$, from $\left(0.6-37.6 \mathrm{~Gy} . \mathrm{cm}^{2}\right)$ with an average $8.165 \mathrm{~Gy} . \mathrm{cm}^{2}$, from $(0.51-49.15$ Gy. $\mathrm{cm}^{2}$ ) with an average $17.0 \mathrm{~Gy} . \mathrm{Cm}^{2}$, from $\left(5.2-101.3 \mathrm{~Gy} . \mathrm{cm}^{2}\right)$ with an average 40.1 Gy. $\mathrm{cm}^{2}$ and from (53-175 Gy. $\mathrm{cm}^{2}$ ) with an average $117.7 \mathrm{~Gy} . \mathrm{cm}^{2}$ respectively. From the data obtained, it is obvious that there are a significant positive correlation between Dose Area Product (DAP) and BMI. Patients with BMI more than $30 \mathrm{Kg} / \mathrm{m}^{2}$ need more radiation dose compared to patients with BMI lower than $30 \mathrm{Kg} / \mathrm{m}^{2}$.

Patients with high BMI require more radiation dose in comparison to those with the small BMI. Due to the high radiation exposure during interventional procedures, it is important to monitor patient dose and awareness should be taken to reduce dose. DAP can be used as an appropriate measure of radiation exposure to patients especially in the absence of quality assurance programme in the department.
\end{abstract}

Key Words: Body mass index, Interventional cardiac processes, Radiation dose

\section{1- Introduction}

Interventional radiological procedures are increasingly used for the diagnosis and the treatment in clinical practice. They have many advantages such as improving the diagnostic quality of examinations and replacing surgery for the treatment. The interventional procedures are faster and cause less traumas and less complications following the interventional treatment. Patients can also recover soon from interventional procedures [1]. The disadvantages of Interventional radiological procedures is that it may lead to very high radiation doses due to exposure in both patients and medical professionals.

Interventional cardiac procedures are known to give high radiation doses to patients because of prolonged use of fluoroscopy, multiple cine runs, and the complexity of the 
procedures [2]. The radiation exposure issue in cardiac catheterizations is particularly relevant for infants and children because of their higher radio sensitivity compared with adults, the large fraction of the body irradiated by the x-ray beam, and the probable need to repeat the procedure [3]. In addition, cardiac catheterizations are being increasingly used for therapeutic purposes, possibly resulting in higher patient radiation doses [4]. When these facts are taken into account, there is a strong need to evaluate the doses delivered to patients who undergo such high-dose x-ray examinations.

The most common procedures are Patent Ductus Arteriosus (PDA), percutaneous Coronary Intervention (PCI), Balloons Pulmonary Valvotomy (BPV), Pulmonary Stenosis (PS), Artial Septal Defect (ASD), Ventricular Septal Defect (VSD), Coronary Arterial Occlusions (CAO), Coronary Angiography (CA), Percutaneous Transluminal Coronary Angioplasty (PTCA), coils, etc. All these procedures contribute to high accumulated radiation doses to the patient and the staff [5-7].

In the literature, various methods have been used to record the radiation dose to which patients have been exposed. Two of the most common ones are DAP and effective dose. DAP is a simple method, easy to measure and is the total amount of radiation emitted by the X-ray equipment. The most commonly used quantities are fluoroscopy time and DAP followed by the number of cine frames and effective dose. DAP (measured in $\mathrm{Gy} \cdot \mathrm{cm}^{2}$ ) is the product of the dose in air in a given plane by the area of the irradiating beam and is independent of the distance from the x-ray source because the decrease in dose with distance matches the increase in area. DAP is the initial quantity not only for estimating patient skin dose but for first establishing the stochastic risk of patients, characterized by effective dose (E) . DAP is measured by an ionization chamber incorporated into the $\mathrm{x}$-ray equipment and includes field non-uniformity effects such as anode-heel effect and use of beam-equalizing shutters (lung shutter). However it does not provide any information regarding the spatial distribution of the entrance beam on patient's skin [8-10]. Fluoroscopy time (usually measured in minutes) is a non-dosimetric quantity; however it is widely used to evaluate patient dosimetry since it is readily available and still the only dose metric routinely employed in many interventional laboratories. Nevertheless it does not incorporate information about dose rate and skin entrance ports [11]. Cine time and cine frames (measured in seconds and number respectively) are also non-dosimetric quantities which are readily available but have the same limitations as fluoroscopy time.

Increasing patient (BMI) results in greater scatter radiation during fluoroscopy, yet the impact of patient BMI on nurse radiation dose during coronary angiography has not been studied [12].

The aim of the present study was to assess whether patients with a larger BMI require longer fluoroscopy time or a larger radiation dose during interventional cardiology procedures.

\section{2- Methods and material}

\subsection{Patient characteristics}

A total of 59 patients (36 females and 24 males) were monitored in cardiac laboratories, El -Demrdash hospital, Cairo, Egypt, with age ranged from new born to 32 years. The study was conducted for both diagnostic and interventional procedures as shown in table 1 . 
J. Sci. Res. Sci.,Vol.(35), 2018

Table (1) No. of patients conducted the diagnostic and interventional procedures

\begin{tabular}{|c|c|c|c|c|}
\hline \multirow{2}{*}{ Clinical Indication } & \multicolumn{2}{|c|}{ Diagnostic } & \multicolumn{2}{c|}{ Interventional } \\
\cline { 2 - 5 } & Male & Female & Male & Female \\
\hline PDA & 6 & 8 & 2 & 0 \\
\hline BPV & 3 & 3 & 0 & 1 \\
\hline Hemodynamic study & 1 & 2 & 0 & 0 \\
\hline ASD & 1 & 2 & 2 & 3 \\
\hline PCI & 0 & 1 & 3 & 0 \\
\hline VSD & 0 & 0 & 2 & 1 \\
\hline PS & 3 & 4 & 0 & 3 \\
\hline primarily study & 0 & 9 & 0 & 0 \\
\hline CAO & 0 & 0 & 1 & 0 \\
\hline
\end{tabular}

Patient data were registered including patient demographics (sex, weight, height, (BMI) and age) as shown in table 2.

Table (2) Clinical characteristics of the studypatient

\begin{tabular}{|c|c|c|c|c|c|c|}
\hline & No. & $\begin{array}{c}\text { Age } \\
(\text { Years })\end{array}$ & $\begin{array}{c}\text { Height } \\
(\mathrm{Cm})\end{array}$ & $\begin{array}{c}\text { Weight } \\
(\mathrm{Kg})\end{array}$ & $\begin{array}{c}\text { BMI } \\
\left(\mathrm{Kg} / \mathrm{m}^{2}\right)\end{array}$ & $\begin{array}{c}\text { F.T } \\
(\mathrm{min})\end{array}$ \\
\hline All & 59 & $(1 \mathrm{M}-32 \mathrm{Y})$ & $\begin{array}{c}109 \\
(50-176)\end{array}$ & $\begin{array}{c}24 \\
(3-80)\end{array}$ & $\begin{array}{c}15.78 \\
(8.65-29.38)\end{array}$ & $\begin{array}{c}13 \\
(2-75)\end{array}$ \\
\hline Diagnostic & 43 & $(1 \mathrm{M}-25 \mathrm{y})$ & $\begin{array}{c}98 \\
(50-172)\end{array}$ & $\begin{array}{c}17.5 \\
(3-62)\end{array}$ & $\begin{array}{c}14.7 \\
(8.65-25.25)\end{array}$ & $\begin{array}{c}7 \\
(2-75)\end{array}$ \\
\hline Interventional & 16 & $(2 \mathrm{Y}-32 \mathrm{Y})$ & $\begin{array}{c}136 \\
(86-176)\end{array}$ & $\begin{array}{c}39 \\
(11.5-80)\end{array}$ & $\begin{array}{c}18.3 \\
(13.2-29.38)\end{array}$ & $\begin{array}{c}24 \\
(12-55)\end{array}$ \\
\hline
\end{tabular}

*M: Month, Y: Year

\subsection{Measurement of Radiation Dose and fluoroscopy time}

All procedures were performed using Innova IGS 520, France image intensifier system. The system was set to pulsed cine acquisition at 7.5, 15, 30 frames/second. The tube angulations were adjusted to obtain optimal views. The system records the total radiation dose emitted during the whole procedure as (DAP). Data obtained are the total radiation exposure during combined fluoroscopy and cine image acquisition and expressed in Gy. $\mathrm{cm}^{2}$. According to the regular maintenance protocol, the image intensifier is calibrated yearly. The fluoroscopy time used in each case was recorded. The numbers of images obtained during a procedure were not automatically registered and thus, were not included in the database.

For radiation dose evaluation, Patients were divided into different categories according to their BMI (the weight $(\mathrm{kg})$ of the patient divided by the square of the height $\left(\mathrm{m}^{2}\right)$ ). Group A with BMI $<10 \mathrm{Kg} / \mathrm{m}^{2}$, Group B for those with BMI 10-15 Kg/m ${ }^{2}$, Group C for those with BMI $15-20 \mathrm{Kg} / \mathrm{m}^{2}$, Group D for those with BMI $20-25 \mathrm{Kg} / \mathrm{m}^{2}$ and Group E for those with BMI $25-30 \mathrm{Kg} / \mathrm{m}^{2}$. 


\subsection{Statistical Analysis}

Data analysis was performed using GraphPad Prism ${ }^{\circledR}$ version 7. Differences between the two groups of patients in terms of radiation dose values were evaluated for statistical significance. Differences were considered significant at correlation $\mathrm{P}<0.05$.

\section{3- Results and discussion}

The radiation doses were significantly greater for patients with higher BMI. The linear regression analysis performed for data from interventional cardiology results. The statistical test demonstrated positive correlation $\left(\mathrm{P}<0.0001, \mathrm{r}^{2}=0.326\right)$ between patients BMI and radiation dose (DAP) during interventional cardiac processes as shown in Figure (1). This finding suggests that the increased dose is likely due to x-ray output from the fluoroscope traversing a greater tissue mass.

\section{B M I\& D A P}

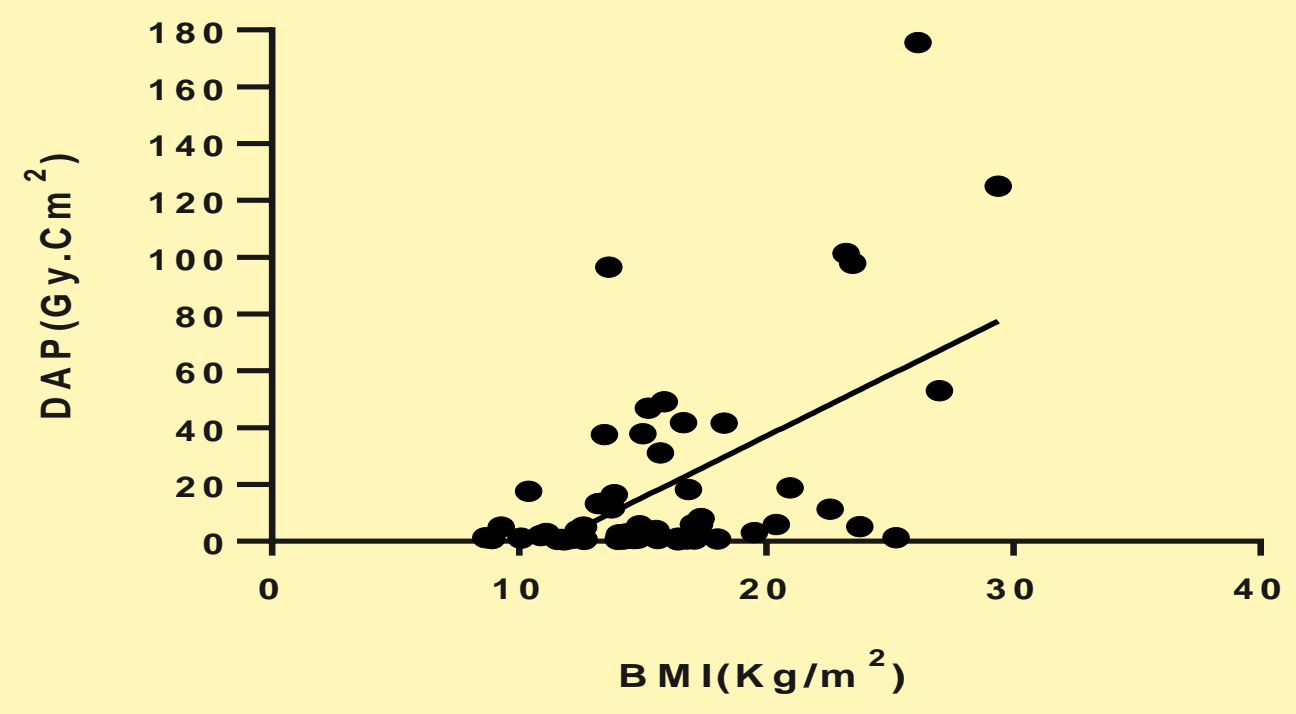

Figure (1): the variation of radiation dose $\left(\mathrm{Gy} . \mathrm{cm}^{2}\right)$ with BMI

When patients were divided according to their BMI into the five groups, with BMI < $10,10-15,15-20,20-25$, and $>30 \mathrm{~kg} / \mathrm{m}^{2}$, the mean radiation exposure dose in each group were calculated and presented in table 3 as mean \pm standard deviation. The mean radiation dose exposure in each group was $2.9,8.2,17.0,40.1$, and $117.7 \mathrm{~Gy} \cdot \mathrm{m}^{2}$ respectively, $(\mathrm{P}<0.0001)$.

From the data obtained, the patients with a BMI $>30 \mathrm{~kg} / \mathrm{m}^{2}$, require more radiation in comparison to patients with BMI < 10, 10-15, 15-20, 20-25 kg/m², and BMI $>30 \mathrm{~kg} / \mathrm{m}^{2}$. Many factors affect patient radiation dose such as X-ray system set-up, type of procedures (interventional or diagnostic), the complexity of the procedure, operator technique and clinical practice, all play a part. 
Table (3) Patients Radiation dose (DAP) with different BMI

\begin{tabular}{|c|c|c|c|c|c|c|c|}
\hline \multirow{3}{*}{$\begin{array}{c}\mathrm{BMI} \\
\mathrm{Kg} / \mathrm{m}^{2}\end{array}$} & \multicolumn{4}{|c|}{ patient } & \multirow{3}{*}{ Total No. } & \multirow{3}{*}{$\begin{array}{c}\text { Age } \\
\text { Mean } \\
\text { (min.-max) }\end{array}$} & \multirow{3}{*}{$\begin{array}{c}\text { DAP }\left(\mathrm{Gy} \cdot \mathrm{Cm}^{2}\right. \\
\text { Mean } \\
\text { (max-min) }\end{array}$} \\
\hline & \multicolumn{2}{|c|}{ male } & \multicolumn{2}{|c|}{ female } & & & \\
\hline & $\mathrm{D}$ & I & $\mathrm{D}$ & I & & & \\
\hline $\begin{array}{c}\text { Group A } \\
<10\end{array}$ & 2 & 0 & 2 & 0 & 4 & $\begin{array}{c}0.7 \\
(0.4-1)\end{array}$ & $\begin{array}{c}2.9 \\
(0.9-4.3)\end{array}$ \\
\hline $\begin{array}{l}\text { Group B } \\
10-15\end{array}$ & 9 & 2 & 13 & 3 & 28 & $\begin{array}{c}3 \\
(0.07-8)\end{array}$ & $\begin{array}{c}8.2 \\
(0.6-37.6)\end{array}$ \\
\hline $\begin{array}{c}\text { Group C 15- } \\
20\end{array}$ & 2 & 6 & 7 & 2 & 19 & $\begin{array}{c}7 \\
(0.42-17)\end{array}$ & $\begin{array}{c}17.0 \\
(0.5-49.2)\end{array}$ \\
\hline $\begin{array}{l}\text { Group D } \\
20-25\end{array}$ & 1 & 1 & 3 & 1 & 6 & $\begin{array}{c}19 \\
(11-25)\end{array}$ & $\begin{array}{c}40.1 \\
(5.2-101.3)\end{array}$ \\
\hline $\begin{array}{l}\text { Group E } \\
25-30\end{array}$ & 0 & 1 & 0 & 2 & 3 & $\begin{array}{c}26 \\
(19-32)\end{array}$ & $\begin{array}{c}117.7 \\
(53-175)\end{array}$ \\
\hline
\end{tabular}

*D means diagnostic, I means Interventional

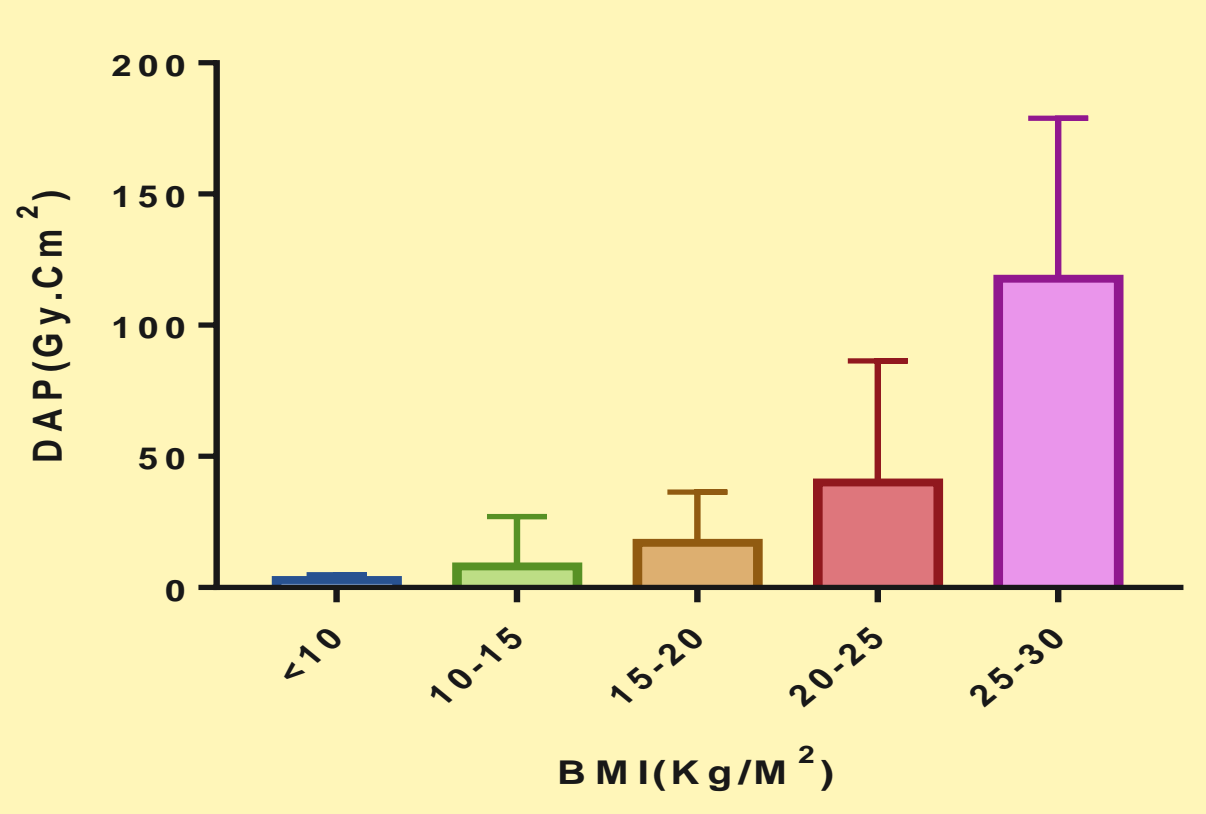

Figure 2: Radiation dose to patients vs. BMI of each group

From the obtained data, the mean exposure dose is affected by the BMI and the type of procedure (diagnostic or interventional). For group A, the DAP was ranged from $(0.9-4.3$ Gy. $\mathrm{Cm}^{2}$ ) with average 2.9 for diagnostic procedures. For group B, the DAP was ranged from $\left(0.6-16 \mathrm{~Gy} . \mathrm{Cm}^{2}\right)$ with average 2.4 for diagnostic procedures, while ranged from $(11.7-37.6$ Gy. $\mathrm{Cm}^{2}$ ) with average 34.5 for the interventional procedures. For group C, the DAP was ranged from $\left(0.5-7.9 \mathrm{~Gy} . \mathrm{Cm}^{2}\right)$ with average 1.2 for diagnostic procedures while, ranged from $\left(18-49.2 \mathrm{~Gy} . \mathrm{Cm}^{2}\right)$ with average 37.9 for the interventional procedures. For group D the DAP was ranged from $\left(5.9-18.75 \mathrm{~Gy} . \mathrm{Cm}^{2}\right)$ with average 10.3 for diagnostic procedures, while, ranged from $\left(97-101 \mathrm{~Gy} . \mathrm{Cm}^{2}\right)$ with average 99.6 for the interventional procedures. For group E, the DAP ranged from $\left(53-175 \mathrm{~Gy} \cdot \mathrm{Cm}^{2}\right)$ with average 117.7 for the interventional procedures. 
The mean value of the fluoroscopic time was 12.56 minutes. Figure (3), shows that there is no significant difference between patients of different BMI and the fluoroscopic time.

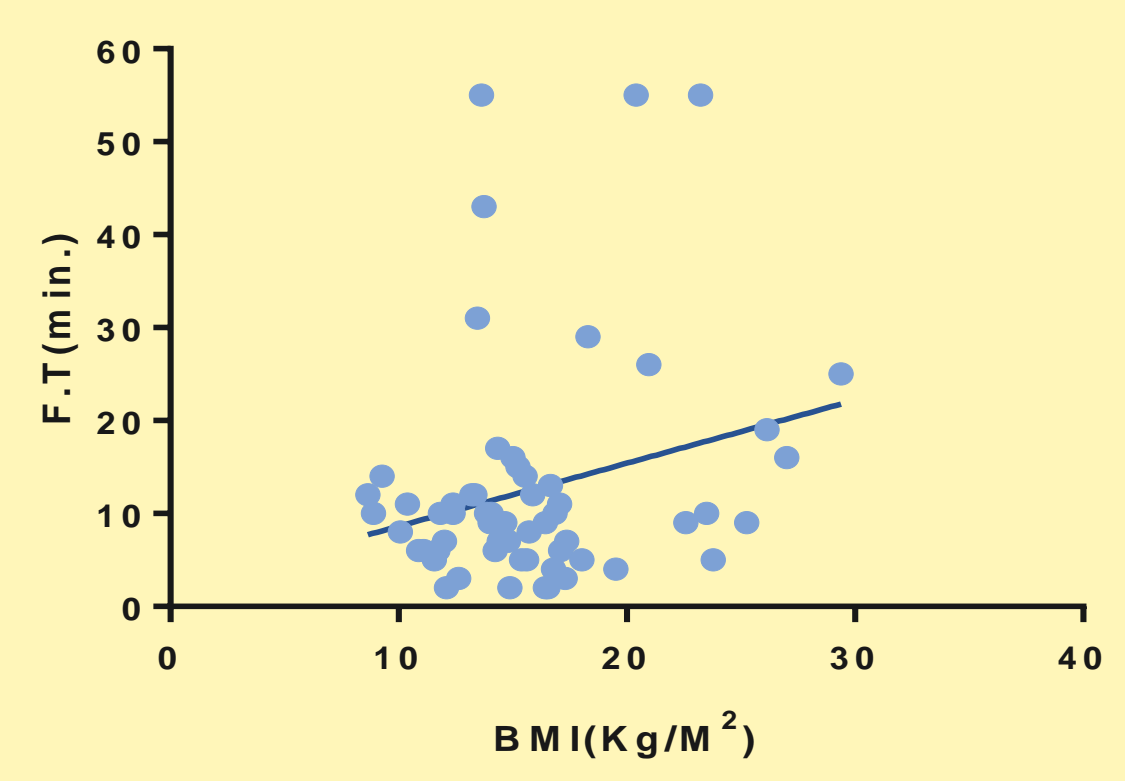

Figure (3): The correlation between BMI and fluoroscopic time

\section{Conclusion}

In conclusion, the study has shown that a patient's body mass index has a significant effect on the amount of radiation delivered during interventional radiological deals. Cumulative DAP can serve as online monitor to provide the immediate readable dose. So, The DAP at the end of the procedure in patient's record is necessary.

\section{References}

AC. Glatz, KS. Purrington, A. Klinger, AR. King, J. Hellinger, X. Zhu, et al. Cumulative exposure to medical radiation for children requiring surgery for congenital heart disease. $\mathrm{J}$ Pediatr 2014 Apr;164(4). http://dx.doi.org/10.1016/j.jpeds.2013.10.074

D. Cushman , A. Flis , B. Jensen , Z. McCormick , "The Effect of Body Mass Index on Fluoroscopic Time and Radiation Dose During Sacroiliac Joint Injections", PM R. 2016 Aug;8(8):767-72. doi: 10.1016/j.pmrj.2015.11.008. Epub 2015 Nov 22

DI. Papadopoulou, TK. YakoumakisEN,Makri, PH. Sandilos, BD. Thanopoulos, EKGeorgiou. Assessment of patient radiation doses during transcatheterclosure of ventricularand atrial septal defects with Amplatzer devices. Catheter CardiovascInterv 2005Jul;65(3):434-41.

European Community Council Directive 97/43 Euratom of 30 June 1997, "on health protection of individuals against the dangers of ionizing radiation in relation to medical exposure Off", European journal of medical physics. 1997; L180:22-27. 
Jankowski, J., Chruscielewski, W., Olszewski, J., \& Cygan, M. (2002), “System for personal dosimetry in interventional radiology", Radiation Protection Dosimetry, Volume 101, Issue14,August2002,P.P221-224, https://doi.org/10.1093/oxfordjournals.rpd.a005971

JL. Georges, L. Belle, C. Ricard, S. Cattan, F. Albert, JL. Hirsch, et al. RAY'ACT investigators. Patient exposure to X-rays during coronary angiography and percutaneous transluminal coronary intervention: results of a multicenter national survey. Catheter CardiovascInterv 2014 Apr 1;83(5):729-38. http://dx.doi.org/10.1002/ccd.25327.

K. Chida, H. Saito, H. Otani, M. Kohzuki, S. Takahashi, S. Yamada ,et al. Relationship between fluoroscopic time, dose-area product, body weight, and maximum radiation skin dose in cardiac interventional procedures. American Journal of Roentgenology. 2006; 186(3):774-8.

N. Journy, S. Sinno-Tellier, C. Maccia, A. Le Tertre, P. Pirard, P. Pagès, et al. Main clinical, therapeutic and technical factors related to patient's maximum skin dose in interventional cardiology procedures. British journal of radiology. 2012;85(1012):433-42.

S. Balter "Methods for measuring fluoroscopic skin dose", PediatrRadiol. 2006; 36(Suppl 14):136-40, PMC free article, PubMed\& AJ. Einstein, KW. Moser, RC. Thompson, MD. Cerqueira, MJ. Henzlova. "Radiation dose to patients from cardiac diagnostic imaging", Circulation 2007;116:1290-305, PubMed

S. Giordano Radiation-Induced Skin Injuries During Interventional Radiography Procedures. Journal of Radiology Nursing. 2010;29(2):37-47.

S. Neil, C. Padgham, C. Martin. A study of the relationship between peak skin dose and cumulative air kerma in interventional neuroradiology and cardiology. Journal of Radiological Protection. 2010;30(4):659.

S. Van de Putte, F. Verhaegen, Y. Taeymans, et al. "Correlation of patient skin doses in cardiac interventional radiology with dose-area product”, Br J Radiol. 2000; 73:504 -513 


\section{ملخص باللغة العربية}

دراسة تأثير مؤشر كتلة الجسم علي الجرعة الإثعاعية للمريض أثناء عمليات القلب التداخلية

أسماء صلاح' ، هيام أحمد عبد الغني'، أحمد عادل طه'، حنان محمد دياب'

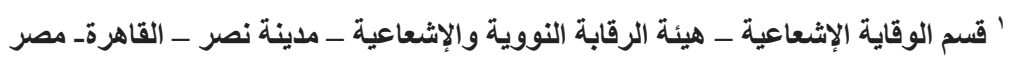

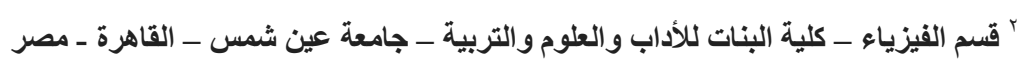

ملخص البحث:

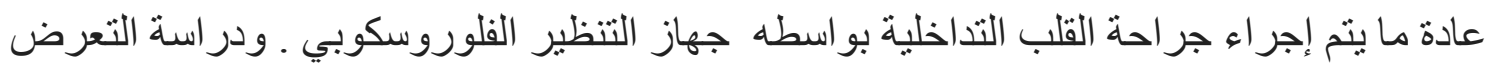
الإشعاعي للمرضى ومقدمي الر عاية لم تتم بشكل شامل ، لا سيما تأثير مؤشر كتلة الجسم (BMI). في هذه الدر اسة تم تقييم الجر عة الإشعاعية التي تلقاها المريض خلال التشخيص وجر احات القلب التدخلية وارتباط ذلك مع مؤشر كتلة جسم المريض (BMI).كما أجري رصد للوقت الفعلي للجر عات الإشعاعية

لستين مريضا تتراوح أعمار هم من حديثي الولادة إلى بr سنة باستخدام مقدار الجرعة (DAP).

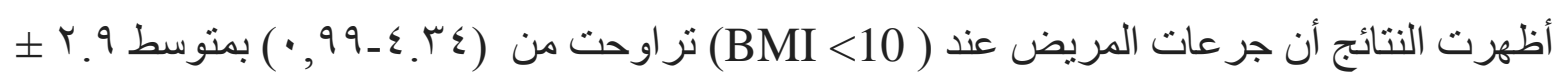

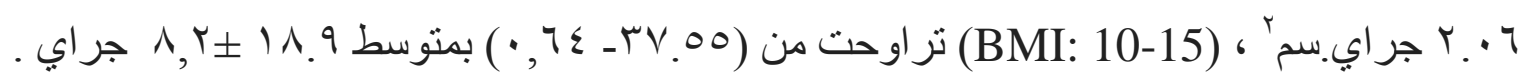
سم'

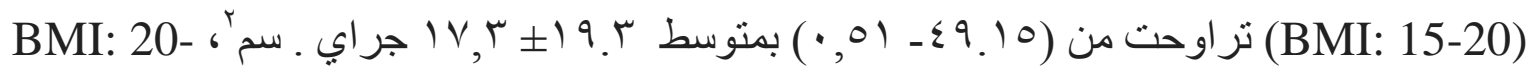

$$
\text { (25) }
$$

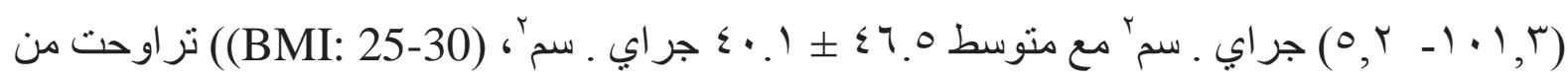

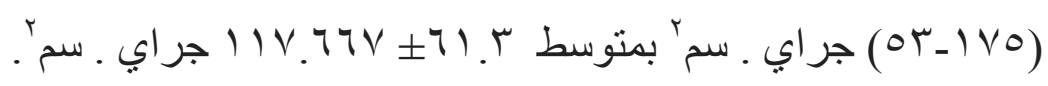

من الدر اسه المقدمه وجد أن مقدار الجرعة (DAP) يزداد مع مؤشر كتلة الجسم ، ولكن لم يُظهِر وقت تنظير الفلوروسكوبي أي علاقه بين مختلف المرضى مع مؤشر كتلة الجسم. 